\title{
Diseases of farmed Atlantic salmon Salmo salar associated with infections by the microsporidian Paranucleospora theridion
}

\author{
S. Nylund ${ }^{1, *}$, L. Andersen ${ }^{1}$, I. Sævareid ${ }^{1}$, H. Plarre ${ }^{1}$, K. Watanabe ${ }^{1}$, C. E. Arnesen ${ }^{2}$, \\ E. Karlsbakk ${ }^{3}$, A. Nylund ${ }^{1}$ \\ ${ }^{1}$ Department of Biology, University of Bergen, 5020 Bergen, Norway \\ ${ }^{2}$ Firda Seafood AS, 5966 Eivindvik, Norway \\ ${ }^{3}$ Institiute of Marine Research, 5817 Bergen, Norway
}

\begin{abstract}
The microsporidian Paranucleospora theridion was discovered in Atlantic salmon Salmo salar suffering from proliferative gill disease in a marine farm in western Norway in 2008. The parasite develops in cells of the reticuloendothelial system, cells important for normal immune function. The aim of this study was to see if $P$. theridion could play a part in some of the diseases with unclear causes in salmon production in Norway, i.e. proliferative gill disease (PGI), pancreas disease (PD), heart and skeletal muscle inflammation (HSMI) and cardiomyopathy syndrome (CMS). P. theridion was present in all areas with salmon farming in Norway, but high prevalence and densities of the parasite in salmon and salmon lice were only seen in southern Norway. This region is also the main area for PGI and PD in Norway. Quantification of pathogens associated with PGI, PD, HSMI and CMS diagnoses showed that $P$. theridion levels are high in southern Norway, and may therefore play a role in susceptibility and disease development. However, among the different diagnoses, fish with PGI are particularly heavily infected with $P$. theridion. Therefore, $P$. theridion appears as a possible primary agent in cases with high mortality in connection with PGI in western Norway.
\end{abstract}

KEY WORDS: Paranucleospora theridion - Atlantic salmon · Microsporidia · Proliferative gill disease · PGI $\cdot$ Pancreas disease $\cdot$ PD

\section{INTRODUCTION}

Production of Atlantic salmon Salmo salar in Norway has for many years suffered from several diseases associated with inflammation of various tissues such as gills, heart and skeletal muscle. These diseases have been named proliferative gill inflammation (PGI; Kvellestad et al. 2005) or proliferative gill disease (PGD; A. Nylund et al. 2008), pancreas disease (PD; McLoughlin et al. 1996) or salmonid alphavirus disease (SAV-disease; Hodneland 2006), heart and skeletal muscle inflammation (HSMI; Watanabe et al. 2003, 2006, Kongtorp et al. 2004a,b), and cardiomyopathy syndrome (CMS; Ferguson et al. 1990). It is believed that viruses may be responsible for CMS (Watanabe et al. 1995, Vågenes et al. 1999, Nylund 2001, Bruno \& Noguera 2009, Fritsvold et al. 2009, O. Haugland et al. unpubl.), HSMI (Watanabe et al. 2003, 2006, Kongtorp et al. 2004a,b, Palacios et al. 2010) and some cases of PGI/PGD (Kvellestad et al. 2005, A. Nylund et al. 2008).

Gill diseases in the production of farmed Atlantic salmon have been an increasing problem in Norway. Several different agents have been associated with these cases of gill disease; Ichthyobodo spp. (Poppe \& Håstein 1982), Neoparamoeba perurans (A. Nylund et al. 2008, Steinum et al. 2008, 2010), Paranucleospora theridion (A. Nylund et al. 2009a,b, S. Nylund et al. 2009, 2010) 'Candidatus Piscichlamydia salmonis' (Draghi et al. 2004, A. Nylund et al. 2008), 'Candidatus 
Clavochlamydia salmonicola' (Karlsen et al. 2008), Atlantic salmon paramyxovirus (Kvellestad et al. 2005), and salmon gill poxvirus (A. Nylund et al. 2008). These agents may all contribute to the gill pathology, hypertrophia, hyperplasia, inflammation and necrosis of gill tissues, but it is not known whether they are primary pathogens or secondary invaders.

It is well documented that 'pancreas disease' is associated with the presence of different strains of SAV (Nelson et al. 1995, McLoughlin et al. 1996, Villoing et al. 2000, Hodneland et al. 2005, Fringuelli et al. 2008). However, the observed disease and mortality in salmon and rainbow trout farms are different from what can be seen in challenge experiments using the different SAV strains (McLoughlin \& Graham 2007). The explanations for this could be presence of different pathogens or other stress factors that may trigger the disease or be the primary cause of disease, reducing SAV to a secondary cause of the observed mortality in farms. Lack of comparable mortality and to a certain extent also pathology has also been observed when comparing challenge experiments using CMS and HSMI homogenates with the observed situation in salmon farms affected by these 2 diseases (Kongtorp et al. 2004a, Fritsvold et al. 2009, A. Nylund pers. obs.). Hence, the trigger or primary causes for these diseases could be environmental factors or other pathogens.

Paranucleospora theridion was first discovered in farmed Atlantic salmon suffering from gill disease in western Norway in 2008 (A. Nylund et al. 2009a,b, S. Nylund et al. 2009, 2010). The parasite was also shown to be present in Salmo trutta, Oncorhynchus mykiss, Lepeophtheirus salmonis and Caligus elongatus. P. theridion has 2 developmental cycles in salmon resulting in 2 different spores (autoinfective spores and environmental spores), and 1 developmental cycle in salmon lice also resulting in 2 different spores (micro- and macrospores; A. Nylund et al. 2009a,b, S. Nylund et al. 2009, 2010). A microsporidian was detected in salmon lice by Freeman et al. (2003), and the partial rDNA small subunit (SSU; GenBank accession no: AJ431366) from this parasite showed $99.3 \%$ similarity to $P$. theridion (accession no: FJ594990), i.e. it differed in 9 out of 1412 nucleotides. Later, Freeman \& Sommerville (2009) published a description of this salmon louse microsporidum, giving it the name Desmozoon lepeophtheirii, and at the same time they corrected the SSU sequence. The new sequence, corrected in March 2010, is identical to that presented earlier from $P$. theridion. These 2 species are clearly synonymous. Since $P$. theridion was the first published name for this parasite (June 2009; A. Nylund et al. 2009b), it will be used in this study.

The first developmental cycle of Paranucleospora theridion in Atlantic salmon takes place mainly in endothelial cells of blood vessels and in leucocytes.
Reduced immune response due to the microsporidian Glugea stephani was shown to lower plasma immunoglobulin M (IgM) levels in the flatfish host, as well as reducing the host immune response against other antigens (Laudan et al. 1986). Nucleospora salmonis has also been shown to stimulate abnormal proliferation of infected lymphoblasts, and the spread of these in tissue can lead to a leukaemia-like condition (Hedrick et al. 1990, 1991).

The aim of the present study was to look at possible connections between PGI, PD, HSMI and CMS and known pathogens that may be present during the development of these diseases with a special emphasis on Paranucleospora theridion. In this study, fish from 55 farms suffering from the above-mentioned diseases and distributed along the areas of the Norwegian coast with salmon farming were collected and screened for the presence of a variety of known pathogens. The possible impact of $P$. theridion in the development of these diseases is discussed.

\section{MATERIALS AND METHODS}

Material. The present study examined moribund farmed Atlantic salmon and rainbow trout Oncorhynchus mykiss from 8 counties along the Norwegian coast (Table 1). All but 1 of the farms had been diagnosed by a local veterinarian or by the official veterinary service. In total, 55 farms were part of the study, and a minimum of 10 fish from each farm were screened for a selection of known pathogens in addition to the suspected causative agent. Forty-three of these farms were diagnosed with 1 or more of the 4 diseases (PGI, PD, HSMI and CMS). The remaining 12, of which 1 was a 'healthy' farm, were diagnosed with other diseases (Table 1). A minimum of 3 different tissues (gills, heart, kidney) were sampled from all fish and stored at $-80^{\circ} \mathrm{C}$. Smears made from gills of all fish were screened for bacteria, Ichthyobodo spp., Trichodina spp. and Neoparamoeba spp. by visual examination using a microscope (Leitz Aristplan) at 100×, 400× and 1000× magnification. When the presence of bacteria was suspected, samples were taken for culturing the bacteria.

Isolation of bacteria. Bacteria were isolated from kidney and grown on blood agar plates containing 1.5\% $\mathrm{NaCl}$ or from skin and grown on Cytophaga agar plates. Both types of plates were incubated at $15^{\circ} \mathrm{C}$ for at least $2 \mathrm{wk}$. When growth was observed on the agar plates, selected colonies were identified by sequencing of the $16 \mathrm{~S}$ gene using the general prokaryotic primers EugB27F and Eug1518R, which target this gene (Giovannoni 1991).

DNA/RNA extraction. DNA was extracted from selected tissues using the DNeasy DNA Tissue kit (Qiagen) as recommended by the manufacturer, while 
Table 1. Farms (reference codes) from counties in Norway, diagnoses and month/year (M-Y) of sampling. Also shown are levels of Paranucleospora theridion in Atlantic salmon or rainbow trout. HG09 and STB07 are smolt-production sites ('fw') with added seawater. - om indicates 2 farms with rainbow trout included. Levels of $P$. theridion, I: extreme amounts $\left(\mathrm{C}_{\mathrm{t}}\right.$ value $\left.<10\right)$, II: high amounts $\left(10<\mathrm{C}_{t}<20\right)$, III: moderate amounts $\left(20<\mathrm{C}_{\mathrm{t}}<30\right)$, IV: low amounts $\left(\mathrm{C}_{\mathrm{t}}>30\right)$, Neg: no infection. HSMI: heart and skeletal muscle inflammation; PD: pancreas disease; PGI: proliferative gill disease; CMS: cardiomyopathy syndrome; Flavo: flavobacteriosis; Parvi: parvicapsulosis

\begin{tabular}{|c|c|c|c|c|c|c|c|}
\hline Farm & M-Y & Diagnosis & P. theridion & Farm & M-Y & Diagnosis & P. theridion \\
\hline Rogaland & & & & SFI09 & 01-2009 & PGI & II \\
\hline RA06 & $10-2006^{a}$ & HSMI & II & SFJ09 & 08-2009 & PGI & II \\
\hline RA09 & $01-2009^{a}$ & HSMI/PGI/CMS & III & SFM09 & $11-2009$ & CMS & III \\
\hline $\mathrm{RC} 07$ & $11-2007$ & PD/HSMI/PGI & III & SFL10 & $02-2010$ & PD & II \\
\hline RE08 & $12-2008$ & PD/HSMI/PGI/CMS & II & \multicolumn{4}{|c|}{ Møre \& Romsdal } \\
\hline RB09 & 09-2009 & PGI & II & MRA06 & $01-2006$ & HSMI/PD & IV \\
\hline RF09 & 06-2009 & $\mathrm{PD}$ & III & MRB08-om & $02-2008$ & VHS & III \\
\hline RD09 & 05-2009 & PGI & III & MRD08 & $11-2008$ & PGI & II \\
\hline RG09 & $11-2009$ & PGI & III & MRE08 & $12-2008$ & ERM & IV \\
\hline Hordaland & & & & MRC09 & 09-2009 & PD & III \\
\hline HA03 & 01-2003 & $\mathrm{PD}$ & III & MRF10 & $04-2010$ & HSMI & IV \\
\hline $\mathrm{HC} 05$ & 04-2005 & CMS & III & \multicolumn{4}{|l|}{ Trøndelag } \\
\hline HD07 & $08-2007$ & PD & II & STA06 & $12-2006$ & HSMI & II \\
\hline HF08 & $05-2008$ & PGI & II & STB07-fw & $01-2007$ & HSMI & IV \\
\hline HI09 & 04-2009 & CMS/PD & III & STC07 & $01-2007$ & HSMI & III \\
\hline HJ09 & 04-2009 & CMS & III & STD09 & 05-2009 & PD/winter ulcers & IV \\
\hline HK09-om & 05-2009 & Flavo & Neg & \multicolumn{4}{|l|}{ Nordland } \\
\hline HL09 & 06-2009 & PD & III & NA09 & 08-2009 & IPNV & IV \\
\hline $\begin{array}{l}\text { HM09 } \\
\text { HN09 }\end{array}$ & $\begin{array}{l}06-2009 \\
06-2009\end{array}$ & $\begin{array}{l}\mathrm{PD} \\
\mathrm{PD}\end{array}$ & $\begin{array}{l}\text { III } \\
\text { III }\end{array}$ & \multicolumn{4}{|l|}{ Finnmark } \\
\hline HG09-fw & $11-2009$ & PGI & Neg & FA09 & 04-2009 & Parvi & IV \\
\hline Sogn \& Fjo & dane & & & \multicolumn{4}{|l|}{ Troms } \\
\hline SFA06-07 & $2006-07^{a}$ & PGI & II & TA05 & 03-2005 & HSMI & IV \\
\hline SFA08-09 & $2008-09^{a}$ & PGI & I-II & TI06 & $10-2006$ & PGI & Neg \\
\hline SFB06-07 & $2006-07^{a}$ & PGI/PD & II & TB08 & 05-2008 & Winter ulcers & Neg \\
\hline SFB08-09 & $2008-09^{a}$ & $\mathrm{PGI} / \mathrm{PD}$ & I-II & TH08 & 05-2008 & Winter ulcers & Neg \\
\hline SFK05-fw & $04-2005$ & IPN & Neg & TC09 & 08-2009 & PD & Neg \\
\hline SFH06 & $10-2006$ & $\mathrm{PD}$ & II & TD09 & 08-2009 & Healthy fish & Neg \\
\hline SFF06 & $04-2006$ & $\mathrm{PD}$ & III & TE09 & $10-2009$ & HSMI & \\
\hline SFC07 & 06-2007 & $\mathrm{PD}$ & III & TF09 & 01-2009 & ISAV & IV \\
\hline SFD07 & $11-2007$ & PGI & III & TG09 & 05-2009 & Winter ulcers & Neg \\
\hline SFG08 & $11-2008$ & PGI & I & \multirow{2}{*}{\multicolumn{4}{|c|}{$\begin{array}{l}{ }^{a} \text { Samples from several productions were taken from farms } \\
\text { RA, SFA and SFB }\end{array}$}} \\
\hline SFE09 & 01-2009 & PGI & III & & & & \\
\hline
\end{tabular}

the RNA extraction from tissues was performed as described by Devold et al. (2000). Elution of DNA was performed twice in $50 \mu \mathrm{l}$ distilled $\mathrm{H}_{2} \mathrm{O}$, and the DNA/RNA was stored at $-20^{\circ} \mathrm{C}$.

PCR and real-time PCR. Extracted DNA from tissues of salmon and salmon lice were used to obtain the partial SSU rDNA sequence of Paranucleospora theridion using the primers Nuc-F1 (5'-GCG ATG ATC TGC TCT AGT TGT G-3') and Nuc-R2 (5'-GCT AAT CCT ACT CAT CCG TAA GC-3'), yielding a fragment of $969 \mathrm{bp}$ in size from position 100 to 1091 (GenBank accession no. FJ594981).

The PCR reaction mixture $(50 \mu l)$ contained $1 \times$ ThermoPol reaction buffer (New England BioLabs), $10 \mathrm{mM}$ of each dNTP (Promega), $0.4 \mu \mathrm{M}$ of each primer (Invitrogen), 1 U Taq DNA polymerase (New England BioLabs) and approximately 200 to $300 \mathrm{ng}$ of DNA template. Amplification was performed in a GeneAmp PCR System 9700 machine (Applied Biosystems) at $95^{\circ} \mathrm{C}$ for $5 \mathrm{~min} ; 35$ cycles of $94^{\circ} \mathrm{C}$ for $30 \mathrm{~s}, 50^{\circ} \mathrm{C}$ for $45 \mathrm{~s}$, $72^{\circ} \mathrm{C}$ for $2 \mathrm{~min}$; followed by extension at $72^{\circ} \mathrm{C}$ for $10 \mathrm{~min}$ and a short storage at $4^{\circ} \mathrm{C}$. All PCR products were purified with EZNA PCR cycle pure (Omega Biotek) and sequenced using the Big Dye terminator sequencing kit (Applied Biosystems). Sequencing was performed at the sequencing facility at the University of Bergen (http://seqlab.uib.no/). Sequence data were analysed and assembled using VectorNTI software (Informax). Sequences obtained in the present study were submitted to GenBank.

Using the VersoTM 1-step QRT-PCR Rox kit (Thermo Scientific), extracted total RNA from gill tissues of similar size $(2 \times 2 \times 2 \mathrm{~mm})$ from salmon was tested for the presence of a selection of known 
pathogens: infectious salmon anaemia virus (ISAV; Plarre et al. 2005), salmonid alphavirus (SAV; Hodneland \& Endresen 2006, Andersen et al. 2007), infectious pancreatic necrosis virus (IPNV; Table 2), nervous necrosis virus (NNV; Korsnes et al. 2005), Atlantic salmon paramyxovirus (ASPV; A. Nylund et al. 2008), viral haemorrhagic septicaemia virus (VHSV; Duesund et al. 2010), 'Candidatus Piscichlamydia salmonis' (A. Nylund et al. 2008), a new species of salmon gill chlamydia (Duesund et al. 2010), Flavobacterium psychrophilum (Duesund et al. 2010), Paranucleospora theridion (S. Nylund et al. 2010), Neoparamoeba perurans (Table 2) and Parvicapsula pseudobranchicola (Table 2).

Regression analysis, standard curve slopes $S$ (cycle threshold, $\mathrm{C}_{\mathrm{t}}$, versus log quantity), and amplification efficiency $E\left(E=\left[10^{1 /(- \text { slope })}\right]-1\right)$ were calculated for all assays (Muller et al. 2002). During the real-time RT-PCR screening, a house-keeping gene, elongation factor $1 \alpha$ (ef1 $\alpha$ ) was used as an internal control (Olsvik et al. 2005).

Relative quantification. The endogenous control was used for calculation of the normalised expression (NE) of RNA levels from the different pathogens in the selected tissues using the Microsoft Excel-based computer software Q-Gene (Muller et al. 2002).

The primers and probes used were obtained from Applied Biosystems, and the amounts of probes and primers were optimised for each assay. The real-time master mixture consisted of $6.25 \mu$ l 1-step QPCR Rox Mix (2×), $0.625 \mu \mathrm{l}$ RT Enhancer, together with $0.125 \mu \mathrm{l}$ of Verso Enzyme mix. Primers and probes at their respective concentrations were added to the master mixture and adjusted with double-distilled $\mathrm{H}_{2} \mathrm{O}$ to a total volume of $10.5 \mu \mathrm{l}$ prior to adding $2 \mu \mathrm{l}$ of RNA template. The real-time RT-PCR reaction was run in a 7500 Fast Real-Time PCR System cycler (Applied Biosystems) using the following conditions: reverse transcription at $50^{\circ} \mathrm{C}$ for 15 min followed by activation of the Thermo-Start DNA polymerase at $95^{\circ} \mathrm{C}$ for 15 min prior to amplification with 45 cycles of $95^{\circ} \mathrm{C}$ for
$15 \mathrm{~s}$ and $60^{\circ} \mathrm{C}$ for $1 \mathrm{~min}$ (denaturation and annealing/ extension). The threshold was fixed for all runs, and samples above the threshold were considered positive. Several controls (RNA extraction controls lacking RNA, and no template controls) were included to avoid false positives.

Quantification of Paranucleospora theridion. Spores of $P$. theridion, obtained from salmon lice, were concentrated, washed and counted, and a dilution series was made based on the number of spores in the stock solution. This was done to obtain information about the detection limit for the real-time PCR assay targeting the $16 \mathrm{~S}$ from $P$. theridion. The dilution series ranged from 64250 to 1.2 spores, and both RNA and DNA were extracted from each dilution. In addition, a DNA template dilution series was made based on a PCR product of known size and concentration. The number of templates was calculated based on Avogadro's number $\left(6.02 \times 10^{23}\right)$. These analyses show that RNA or DNA extracted directly from 1.2 spores will give $C_{t}$ values of 35.3 and 34.9, respectively, while using the pure template (from the PCR reaction) resulted in a $\mathrm{C}_{\mathrm{t}}$ value of 31.9 for 12 templates. The analysis of the dilution series gave $C_{t}$ values of 14.0, 18.3, 24.0, 29.3 and 31.3 when extracting RNA directly from $64250,6425,643$, 80 and 40 spores respectively.

Histology. Gill, heart and kidney tissues were sampled from moribund fish (minimum 5 fish per sampling) in several farms and fixed by immersion, at $6^{\circ} \mathrm{C}$, in a modified Karnovsky's fixative, where the distilled water was replaced by Ringer's solution (Nylund et al. 1995). The fixative contained $4 \%$ sucrose. Before embedding in EMBED-812 (Electron Microscopy Sciences), the tissues were stained/post-fixed in $2 \%$ $\mathrm{OsO}_{4}$. Semi- and ultrathin sections were cut on a Reichert-Jung Ultracut E microtome. The ultrathin sections $(30-40 \mathrm{~nm})$ were stained for $1.5 \mathrm{~h}$ in $5 \%$ aqueous uranyl acetate solution and then stained with lead citrate. Semithin sections $(0.5 \mu \mathrm{m})$ were stained with toluidine blue.

Table 2. Real-time PCR assays for Parvicapsula pseudobranchicola (SSU rRNA), Neoparamoeba perurans (SSU rRNA) and infectious pancreatic necrosis (IPN) virus (VP2)

\begin{tabular}{|llll|}
\hline Target & Primer/probe name & Sequence $\left(5^{\prime}-3^{\prime}\right)$ & Amplicon size (nt) \\
\hline P. pseudobranchicola & Parvi-F & TCG TAG TCG GAT GAC AAG AAC GT & \\
& Parvi-probe & CCG TAT TGC TGT CTT TGA & 61 \\
& Parvi-R & AAA CAC CCC GCA CTG CAT & \\
N. perurans & Neo-F & GCT CGT AGT TGG ATTT TGA AGT TTA CA & \\
& Neo-probe & TTA TGA CCC CCT TTG TAT TAG & 79 \\
Neo-R & GGA GAA GTA CAT ATC ACA ACA AAA CAC A & \\
& IPNV-F & ACC CCA GGG TCT CCA GTC & \\
& IPNV-probe & TCT TGG CCC CGT TCA TT & \\
& IPNV-R & GGA TGG GAG GTC GAT CTC GTA & \\
\hline
\end{tabular}


Statistical testing. The non-parametric Mann-Whitney $U$-test was used to examine whether Paranucleospora theridion levels differ in farms with a given diagnosis when compared to farms with other diagnoses. Analyses were restricted to seawater farms from southern Norway (region Rogaland to Sør-Trøndelag), where $P$. theridion infections are common $(\mathrm{N}=43$ farms), and were run both with and without farms rearing rainbow trout $(\mathrm{N}=2)$.

\section{RESULTS}

Fish from 43 of the farms included in this study were diagnosed with PGI, PD, HSMI or CMS, or a combination of these diseases. Of the remaining 12 farms, 4 held fish with winter ulcers (farms STD09, TB08, TH08, TG09) and the other 8 held fish that were diagnosed with infectious pancreatic necrosis (IPN) (farms NA09, SFK05-fw), infectious salmon anaemia (ISA) (farm TF09), viral haemorrhagic septicaemia (VHS) (farm MRB08-om), enteric redmouth (ERM, Yersinia ruckeri) (farm MRE08), cold water disease (Flavobacterium psychrophilum) (farm HK09-om), and parvicapsulosis (Parvicapsula pseudobranchicola) (farm FA09). One farm (TD09) contained fish with no diagnosed disease. The fish infected with VHS virus and $F$. psychrophilum were rainbow trout, while the fish in the other farms were Atlantic salmon.

\section{Proliferative gill inflammation}

All fish diagnosed with PGI were Atlantic salmon and came from seawater sites in western Norway, with 2 exceptions. The salmon in farm TI06 were located in northern Norway, and the salmon in farm HG09-fw were smolt kept at a smolt-production site in western Norway. The salmon in farm TI06 came from a smolt-production site that had experienced an outbreak of gill disease associated with a poxvirus, salmonid gill poxvirus (SGPV; cf. A. Nylund et al. 2006,2008 ). After sea launching in the spring, the fish experienced a new outbreak of gill disease in October. Several pathogens ('Candidatus Piscichlamydia salmonis', Ichthyobodo sp., Parvicapsula pseudobranchicola) were associated with this outbreak, but the SGP virus was not detected. One individual was infected with Exophialia sp. (accession nos. EF115303, EF115304, EF115305). Fish in HG09, a smolt-production site with added seawater, were negative for Paranucleospora theridion, but heavily infected with Flavobacterium psychrophilum, and slightly positive for Yersinia ruckeri, 'Candidatus Clavochlamydia salmonicola' and SAV.
The fish from the other PGI farms had skin haemorrhages, loss of scales and pale gills with a high production of mucus. The gill epithelium showed hypertrophia and hyperplasia, necrosis and invasion of leukocytes (inflammation; Figs. 1 \& 2). Use of transmission electron microscopy (TEM) showed the presence of numerous cells infected with various developmental stages of Paranucleospora theridion (Fig. 3). Inflammation was also observed in kidney, somatic muscle and heart, and high amounts of melanomacrophages were seen in kidney and spleen. High numbers of various developmental stages of $P$. theridion were also present in the cytoplasm of leukocytes and blood vessel endothelial cells (Fig. 4). Darkening of the somatic muscle was observed in a few fish that were heavily infected with $P$. theridion (Fig. 5).

The PGI samples from Atlantic salmon at marine sites in western Norway were diagnosed between August and January, with the exception of 2 samples that had the disease in May (farms HF08 and RD09; Table 1). The mortality in these farms ranged from $10 \%$ to slightly above $80 \%$. Fish from a few of these farms had a light infection with Ichthyobodo sp., Trichodina sp. (accession no. HM583859) or Neoparamoeba perurans (accession no. EU326494, Fig. 6), or a combination of these. One farm (SFA06) had a moderate infection with 'Candidatus Piscichlamydia salmonis', and the other farms had fish that were carriers of this bacterium. None of the fish in the farms was suffering from PD or ISA, but a few fish in some farms were carriers of SAV (farms SFA06-07, SFA08-09, HF08, HG09) and ISA virus (farms SFA08-09, SFJ09). All of these farms had moderate to heavy infections with Paranucleospora theridion (Table 1).

Samples were taken from 2 different generations in farm SFA, i.e. generation SFA06-07 and SFA08-09. The farm was fallowed for nearly 1 yr between the 2 generations. The relative amount of Paranucleospora theridion present in gill tissue was checked from both generations (Fig. 7), and the amount was high during periods (August to January) with mortality. All fish in both generations were infected with Eubothrium sp. and 'Candidatus Piscichlamydia salmonis', a few fish in both generations were carriers of SAV and ISA virus, and only the 2006-2007 generation had carrier fish that were positive for IPN virus. The second generation, 2008-2009, had a few fish with light infections by Parvicapsula pseudobranchicola, a newly recognised species of gill chlamydia and Flavobacterium psychrophilum. The latter bacterium was present in kidneys, but not in gill samples. None of the fish was positive for Atlantic salmon paramyxovirus (ASPV), but both generations had fish that were infected by salmonid gill poxvirus (SGPV; Fig. 8). 


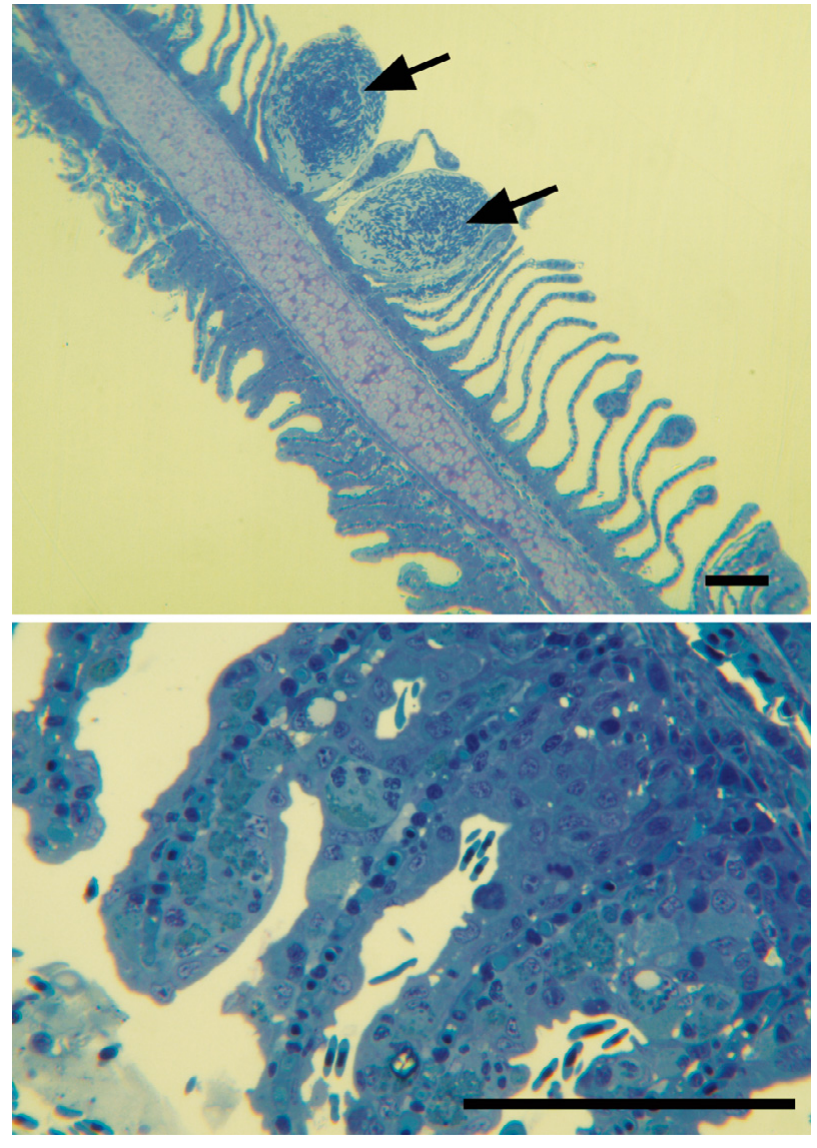

Fig. 1. Salmo salar. Histological changes in the gills of Atlantic salmon suffering from proliferative gill disease (PGI). The changes are dominated by aneurisms (arrows), hyperplasia, inflammation and necrosis. Scale bars $=100 \mu \mathrm{m}$

\section{Pancreas disease}

Fish from 12 farms were diagnosed with PD. All farms are from western Norway with 1 exception, TC09, from Troms (northern Norway). TC09 had received smolt from western Norway, in addition to smolt produced locally. A few fish (3 out of 56) in this farm were lightly infected by Paranucleospora theridion, while there were moderate amounts $\left(\mathrm{C}_{\mathrm{t}}\right.$ values between 20 and 29) of SAV and Parvicapsula pseudobranchicola present in all fish sampled (Fig. 9). Salmon in this farm were sampled at 3 different times (28 August, 9 and 14 October 2009) during outbreak of the disease. The sample from August contained significantly higher amounts of $P$. pseudobranchicola templates in the kidney compared to presence of SAV, while in the first sample from October the difference was smaller; this sample included both kidney and gill tissues showing a higher amount of both pathogens in kidney compared to the gills. In the last
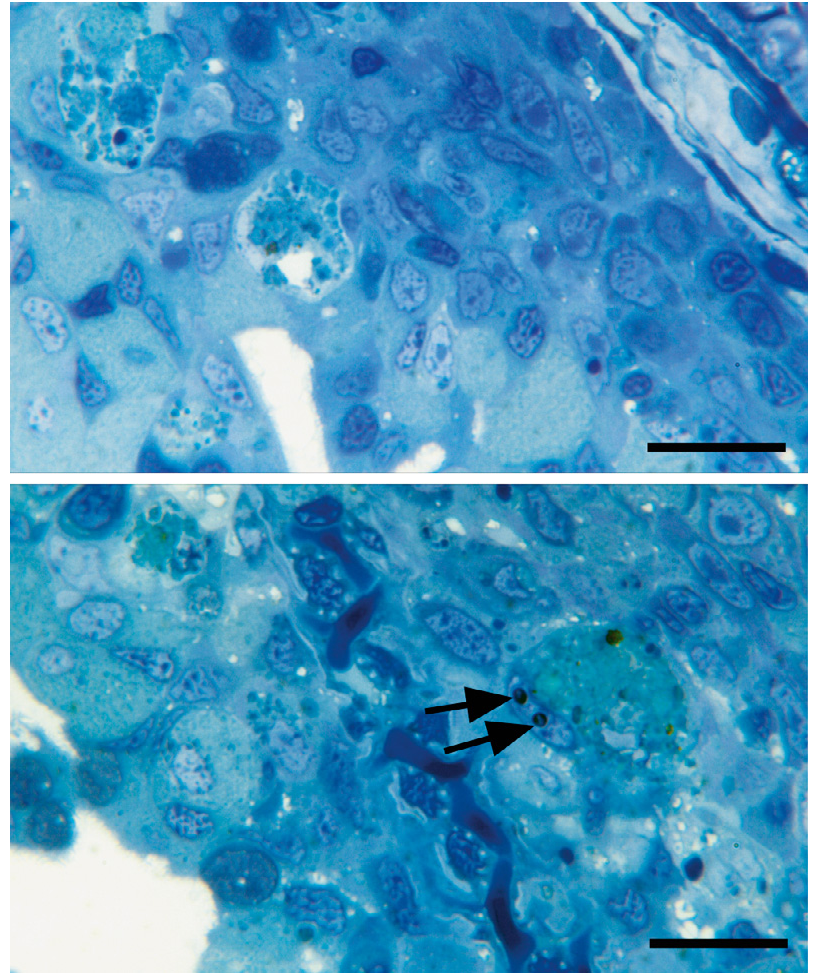

Fig. 2. Paranucleospora theridion infecting Salmo salar. Necrosis of cells in the gills of Atlantic salmon. Two spores (arrows) in host cell nucleus. Scale bars $=20 \mu \mathrm{m}$

sample from October, both the heart and kidney tissues were used for detection of the 2 pathogens, and the heart tissue showed a significantly higher number of SAV templates compared to $P$. pseudobranchicola, while $P$. pseudobranchicola was dominant in the kidney tissues of most individuals. The heart is not a known site for $P$. pseudobranchicola development, while it is considered, together with the gills, as a good tissue for detection of SAV.

The remaining 11 farms diagnosed with PD contained fish that all had moderate to high densities of Paranucleospora theridion and low to moderate amounts of SAV. All fish sampled from these farms were moribund. The prevalence of $P$. theridion was $100 \%$ in all samples, while the prevalence of SAV varied from 5 to $90 \%$. Fish from 4 farms were positive for ISA virus, and IPN virus was present in 2 farms. The clinical signs and the pathology were consistent with that seen in fish diagnosed with PD. In addition, the fish had changes in the gills consistent with presence of $P$. theridion. The PD outbreaks occurred in January $(\mathrm{N}=1)$, February (1), April (1), June (5), August (1), September (1) and October (1). The highest density of $P$. theridion was observed during the PD outbreaks in August, October and February. 

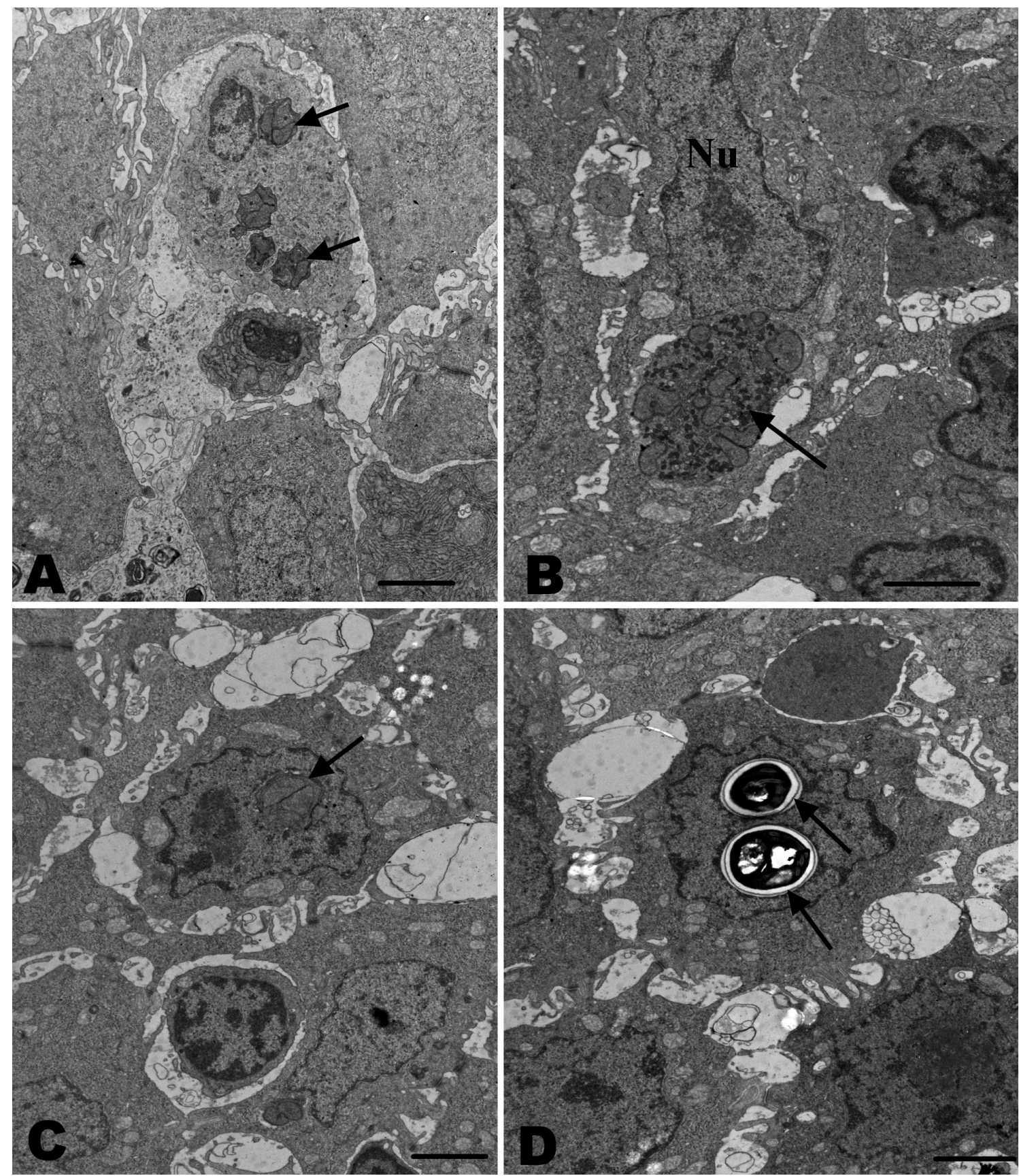

Fig. 3. Paranucleospora theridion infecting Salmo salar. Developmental stages of $P$. theridion in the gills of Atlantic salmon. (A) Sporoblasts (arrows) in the cytoplasm of an unidentified cell. (B) Sporont (arrow) in the cytoplasm of an unidentified cell in the gills. Nu: host cell nucleus. (C) Merontal stage (arrow) in the nucleus of a gill epithelial cell. (D) Two spores (arrows) in the nucleus of a gill epithelial cell. Scale bars $=2 \mu \mathrm{m}$

\section{Heart and skeletal muscle inflammation and cardiomyopathy syndrome}

Fish from 17 farms were diagnosed with HSMI and CMS, or a combination of these 2 diseases and PGI and $\mathrm{PD}$ (Table 1). The majority of these farms are located in southern Norway (Rogaland to Trøndelag), but 2 farms are located in northern Norway, in Troms County (farms TA05 and TE09). The outbreaks in the 17 farms were registered in January ( $\mathrm{N}=4)$, March (1), April (4), September (1), October (3), November (2) and December (2). The salmon in the 2 farms from Troms suffered 


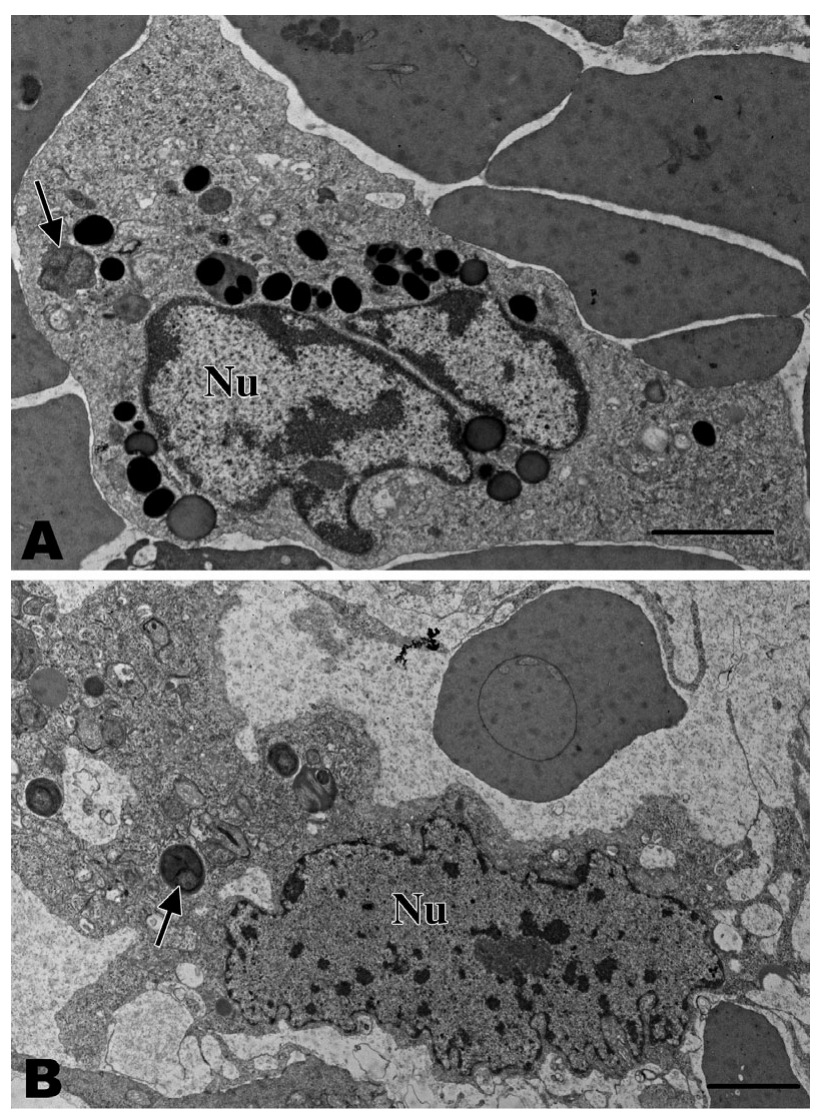

Fig. 4. Paranucleospora theridion infecting Salmo salar. Developmental stages of $P$. theridion in the kidney of Atlantic salmon. (A) Polymorphonuclear leukocyte with a merontal stage (arrow) in the cytoplasm. Nu: host cell nucleus. (B) Blood vessel endothelial cell containing spores (arrow) and sporoblasts in the cytoplasm. Scale bars $=2 \mu \mathrm{m}$

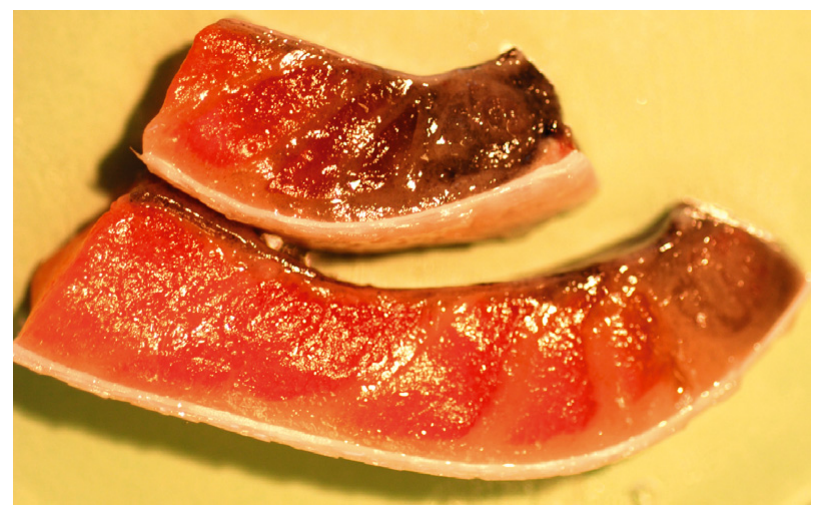

Fig. 5. Paranucleospora theridion infecting Salmo salar. Pigmentation of the somatic muscle in heavily infected Atlantic salmon

from HSMI, and a few fish in one of these (TA05) had a low amount of Paranucleospora theridion. The fish in both farms had moderate amounts of Parvicapsula pseudobranchicola $\left(\mathrm{C}_{\mathrm{t}}\right.$ values between 20 and 30), and

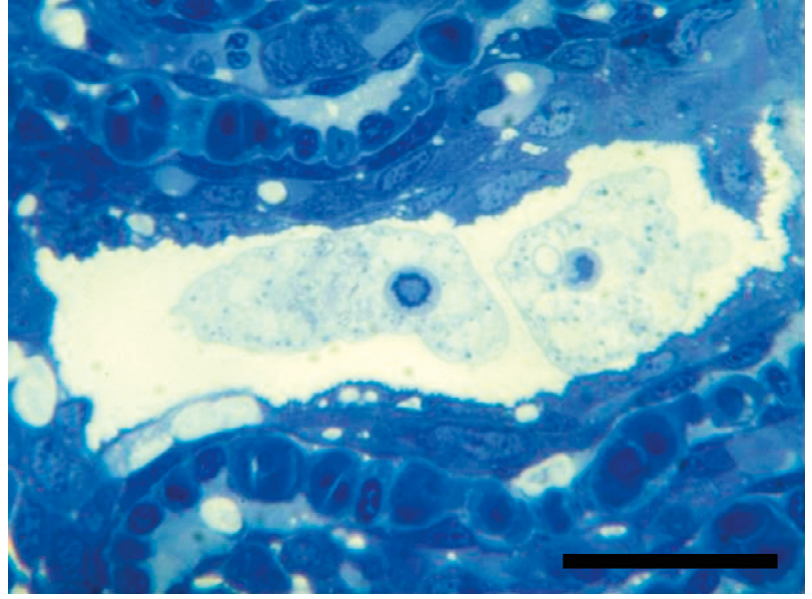

Fig. 6. Neoparamoeba perurans infecting Salmo salar. N. perurans on the gills of salmon in farm SFA (sampled on 31 October 2006). Scale bar $=200 \mathrm{~nm}$

they were negative for the presence of SAV. Salmon in farm TE09 were carriers of ISA virus, but they did not experience an outbreak of ISA.

Salmon in 3 of the remaining 15 farms (MRA06, STB07 and MRF10) had low amounts of Paranucleospora theridion. Two of these (STB07-fw and MRF10) were diagnosed with HSMI, while the third (MRA06) was diagnosed with SAV/HSMI and winter ulcers. A low amount of $P$. theridion was present in the fish in farm MRA06, i.e. 9 out of 10 fish were positive for $P$. theridion while 7 out 10 were carriers of SAV, but all were positive for Moritella viscosa. STB07-fw is a smolt-production site, with added seawater, and a low amount of $P$. theridion (8 out of 16 fish were carriers) was found in the salmon smolt during the outbreak of HSMI. Five of the 16 salmon were carriers of SAV, and they were all strongly positive for presence of Flavobacterium psychrophilum. All fish were negative for ISA virus and IPN virus. The salmon in farm MRF10 had low amounts of $P$. theridion, Parvicapsula pseudobranchicola and 'Candidatus Piscichlamydia salmonis'. A few fish were also positive for ISA virus, but they were all negative for SAV and IPN virus.

All salmon in 3 farms (HC05, HJ09 and SFM09) suffering from CMS had moderate amounts of Paranucleospora theridion (Table 1), and the fish in SFM09 were carriers of SAV. None of the salmon were positive for ISA or IPN viruses.

The salmon suffering from HSMI in RA06 and STA06 had high amounts of Paranucleospora theridion, while there were moderate amounts in salmon from farm STC07. There were also carriers of SAV and ISA virus among the salmon in farms STA06 and STC07, but none in farm RA06. In addition to high amounts of $P$. theridion (range of $C_{t}$ values: 11-16), the salmon in 


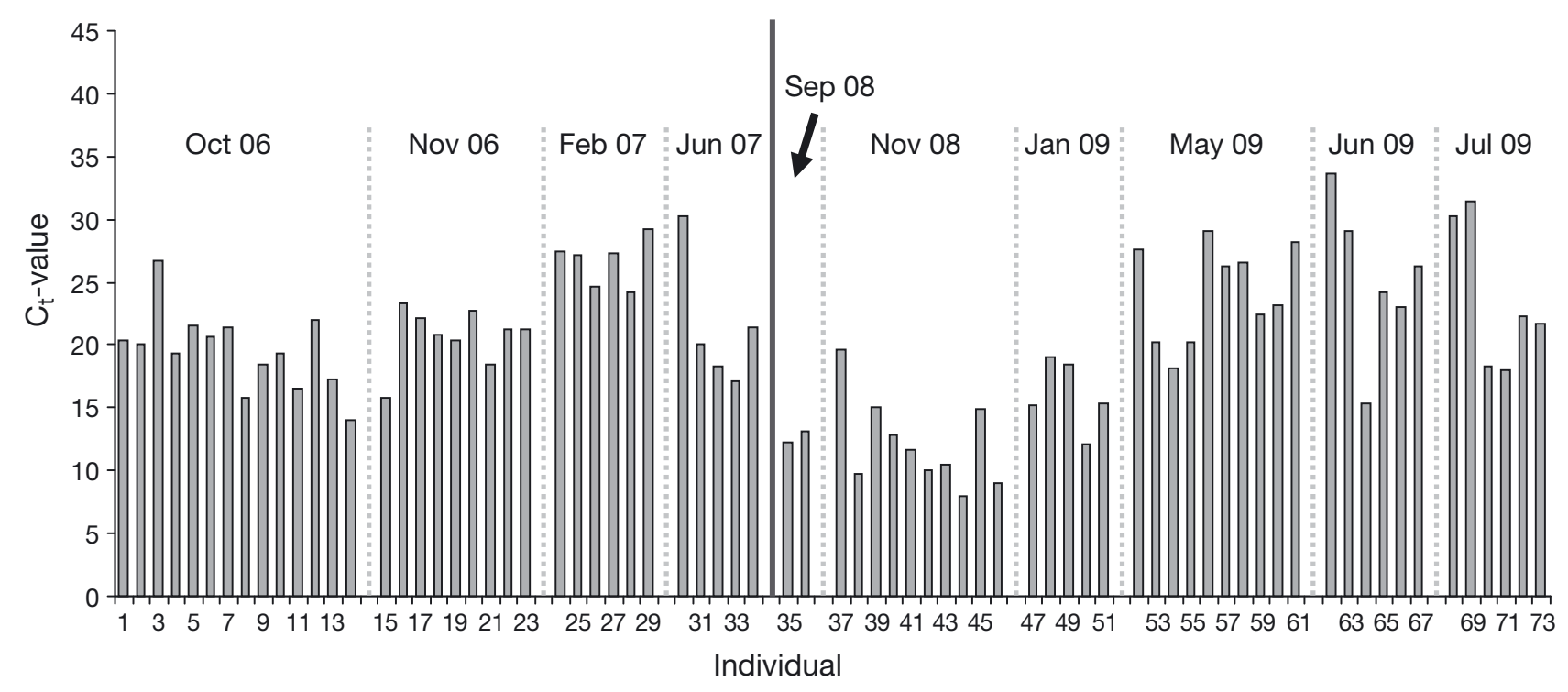

Fig. 7. Paranucleospora theridion infecting Salmo salar. Densities, presented as $\mathrm{C}_{\mathrm{t}}$-values, of $P$. theridion in gills from 2 generations of Atlantic salmon in farm SFA in the periods 2006 to 2007 and 2008 to 2009. Increased mortality was observed in the period July to January

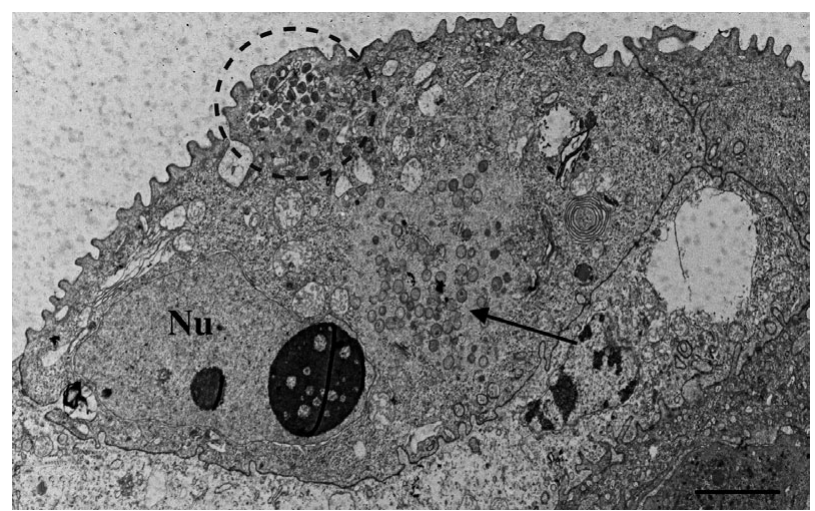

Fig. 8. Presence of salmonid gill poxvirus (SGPV) in farm SFA (sample date: 29 September 2008) showing immature virion in viroplasm (arrow) and intracellular mature virus (circle). $\mathrm{Nu}$ : host cell nucleus. Scale bar $=2 \mu \mathrm{m}$

RA06 were also positive for 'Candidatus Piscichlamydia salmonis'.

The salmon in farms RC07, RE08, HI09 and RA09 suffered from a mixture of diseases and with the exception of the salmon in RE08, they all had moderate amounts of Paranucleospora theridion (Table 1). The salmon in RE08 had high amounts of $P$. theridion, and they were also moderately positive for SAV and carriers of IPN and ISA viruses.

One farm (SFB), diagnosed with PGI/SAV, was followed through a period of $4 \mathrm{yr}$ and 2 separate generations (SFB06-07 and SFB08-09). The first generation (SFB06-07) suffered high mortalities (80\%) and was diagnosed with PGI. The fish were highly positive for
Paranucleospora theridion and 'Candidatus Piscichlamydia salmonis', but some individuals were also positive for SAV and SGP virus. The fallowing period between the generations was about $9 \mathrm{mo}$, and the second generation (SFB08-09) experienced 14\% mortality in the period from September 2008 to February 2009. A new increase in mortality was registered in August 2009, and PD was given as the diagnosis. The relative amount of $P$. theridion present was quantified based on gill samples from salmon in the SFB08-09 generation (Fig. 10). The mortality occurred during the periods with the highest amount of $P$. theridion present in the fish. SAV had been present throughout the production period, but there was a slight increase in the number of SAV-positive fish in August when the PD diagnosis was given. However, the dominant pathogens during this mortality were $P$. theridion and Parvicapsula pseudobranchicola (Fig. 11).

\section{Other diseases}

Salmon in 2 farms (SFK05-fw and NA09) were diagnosed with IPN, and high to moderate amounts of IPN virus were detected in both populations. One of these farms (SFK05-fw) was a freshwater smoltproduction site where salmon suffered high mortalities. In addition to IPN, these fish also suffered from haemorrhagic smolt syndrome, and some fish (50\%) were positive (low amounts) for Flavobacterium psychrophilum. No other pathogens were found. The salmon in the other farm (NA09) diagnosed with IPN 

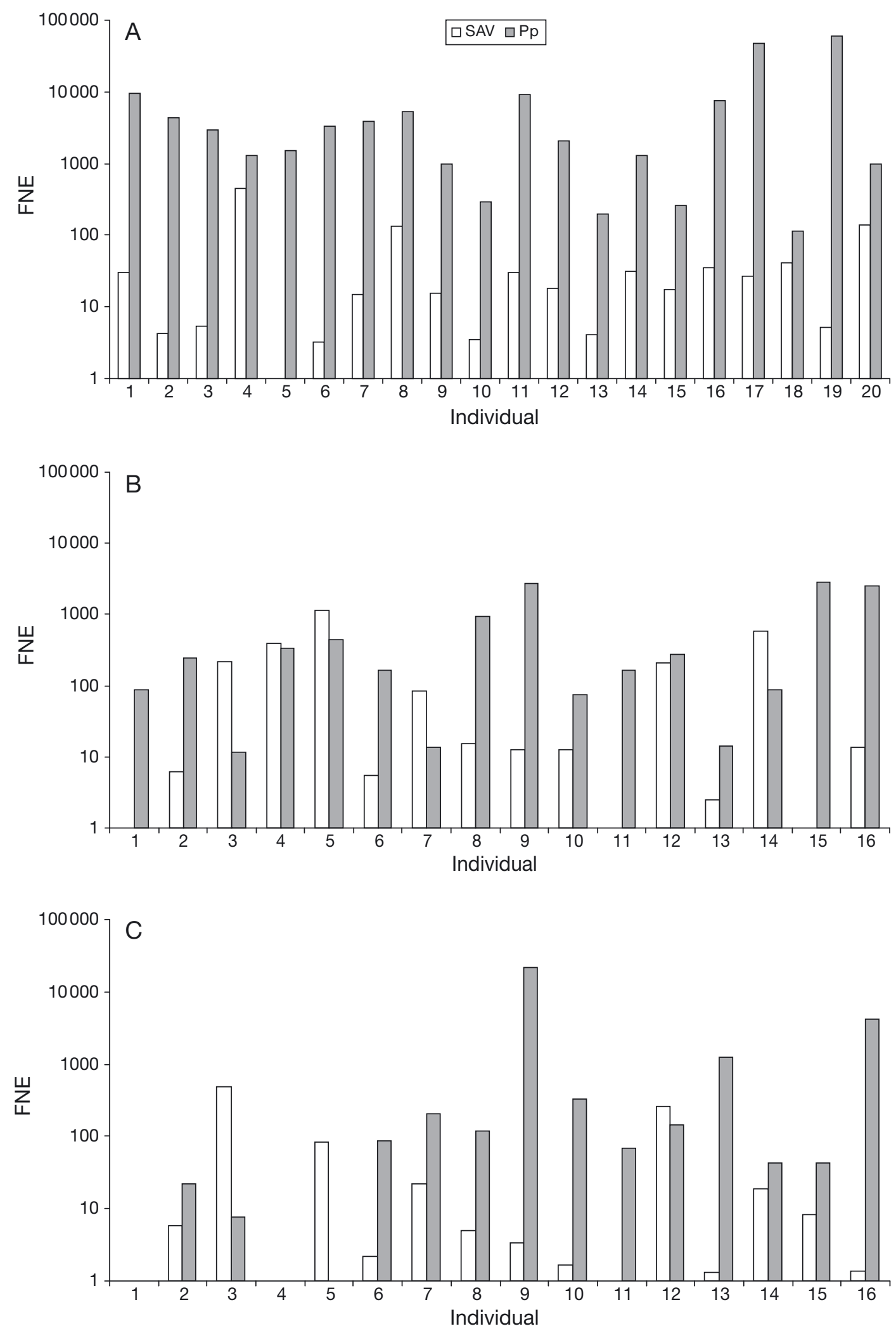

Fig. 9. Normalized expression of salmonid alphavirus (SAV) and Parvicapsula pseudobranchicola (Pp) in farm TC09 presented as fold increase on a logarithmic scale (FNE). The $x$-axis represents individual fish. (A) Kidney (sampled on 28 August 2009). (B) kidney and (C) gills (both sampled on 9 October 2009). (D) Heart and (E) kidney (both sampled on 14 October 2009) 

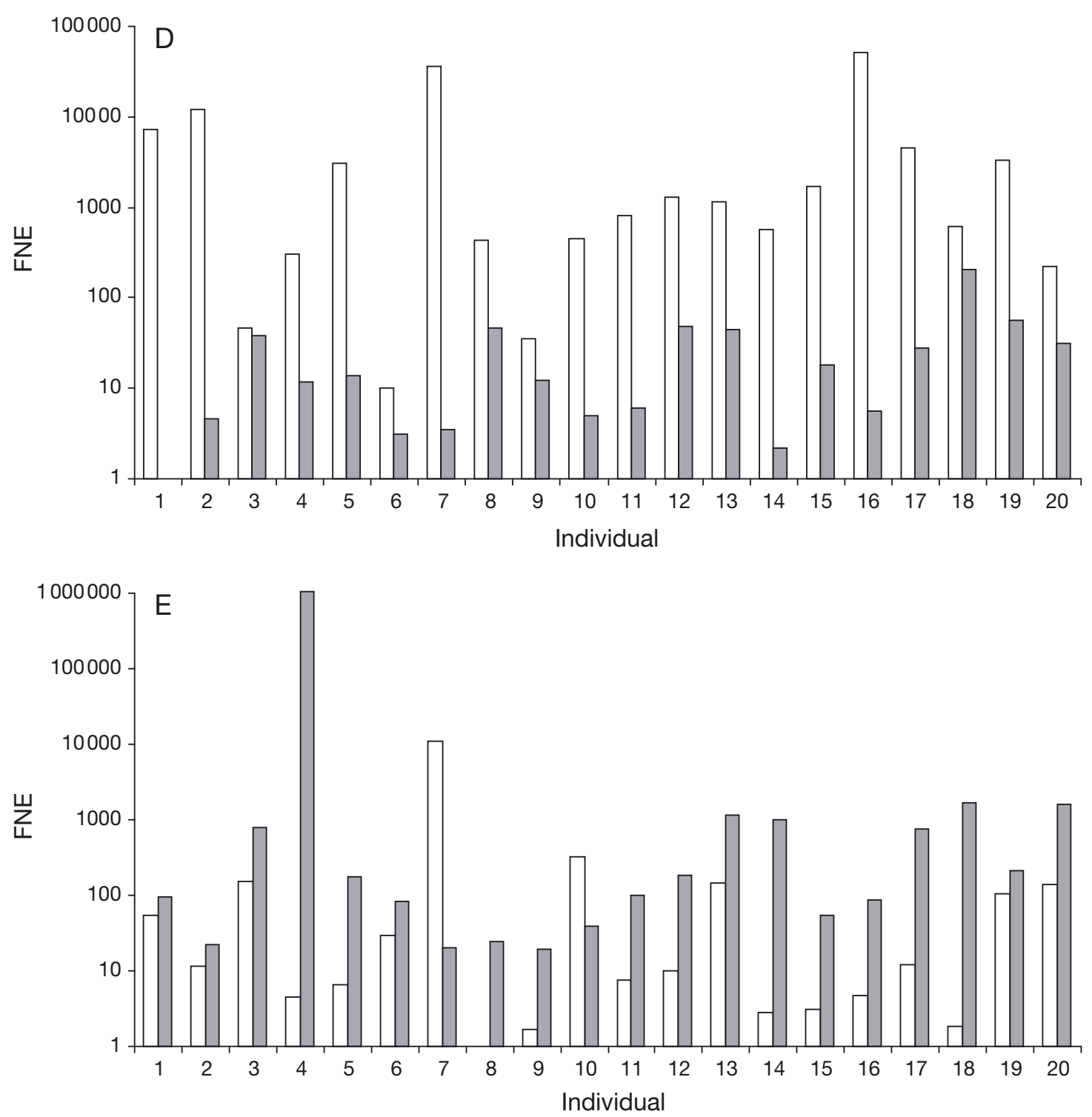

Fig. 9 (continued)

were kept in seawater and suffered about $50 \%$ mortality during the summer months. The salmon in this farm were moderately positive for IPN virus and Parvicapsula pseudobranchicola, and a few individuals were carriers of Paranucleospora theridion (3/15) and SAV (3/15).

All salmon $(\mathrm{N}=10)$ in the farm diagnosed with ERM (MRE08) were strongly positive for Yersinia ruckeri. Low amounts of Paranucleospora theridion were also present in all fish examined, and a few fish were carriers of ISA and IPN virus.

Moribund rainbow trout from a farm diagnosed with VHS in November 2007 (MRB08-om) were collected in February $2008(\mathrm{~N}=10)$. On this collection date, all fish were negative for the presence of VHS virus, but all had moderate amounts of Paranucleospora theridion, and 5 were carriers of IPN virus.

Fish from the most northern county in Norway, Finnmark (farm FA09), were diagnosed with parvicapsulosis, and all fish were moderately positive for presence of this parasite. One fish was positive for Paranucleospora theridion (high $\mathrm{C}_{\mathrm{t}}$ ), and all fish were negative for ISA virus and SAV. Similar results were also obtained for salmon diagnosed with ISA in a farm (TF09) in the neighbouring county Troms. All fish were highly positive for ISA virus, and a few were carriers of SAV and lightly infected with $P$. theridion. Healthy fish $(\mathrm{N}=12)$ from a farm in the same county (TD09) showed 2 carriers of SAV and 1 and 4 fish lightly infected with $P$. theridion and Parvicapsula pseudobranchicola, respectively. 


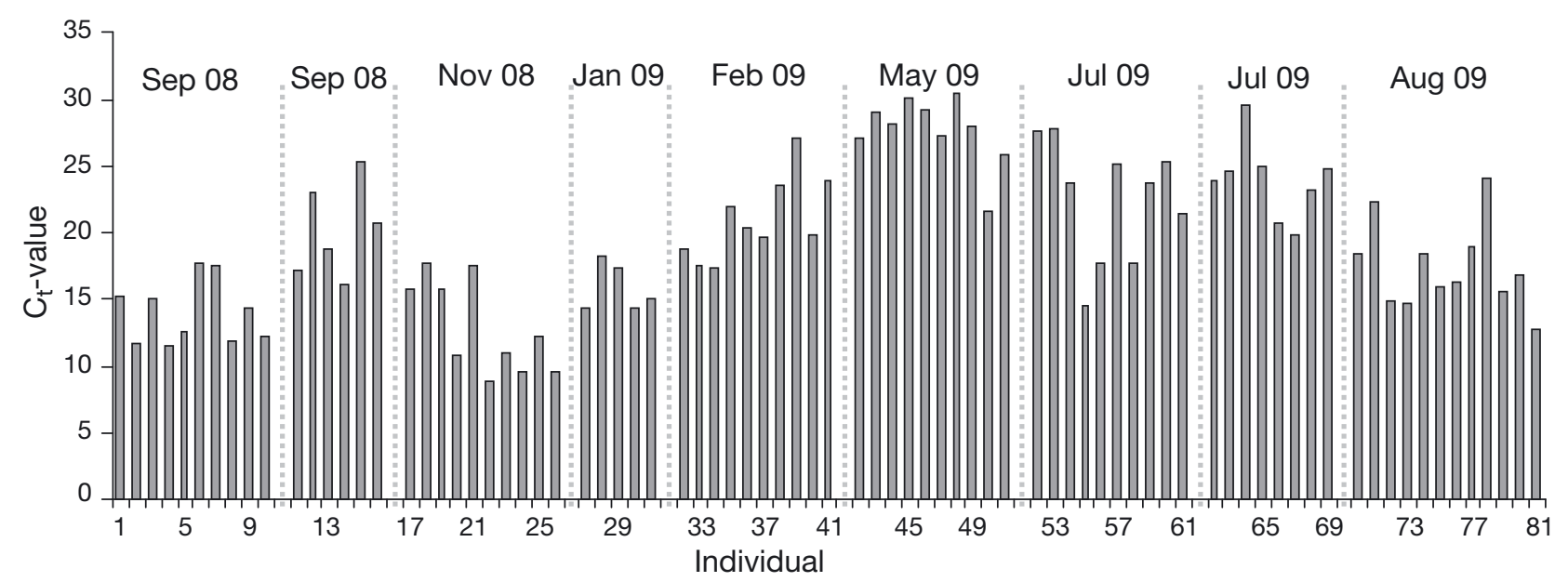

Fig. 10. Paranucleospora theridion infecting Salmo salar. Densities, presented as $\mathrm{C}_{\mathrm{t}}$-values, of $P$. theridion in gills from $1 \mathrm{genera-}$ tion of Atlantic salmon in farm SFB in the period 2008 to 2009. Increased mortality was observed in the months August to January in 2008 and 2009

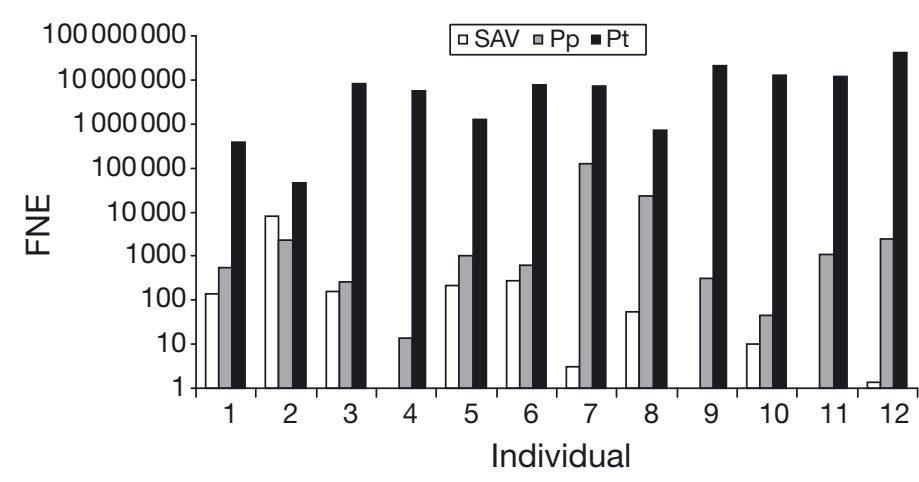

Fig. 11. Densities presented as fold increase of the normalised expression (FNE) of the target genes of salmonid alphavirus SAV, Parvicapsula pseudobranchicola (Pp) and Paranucleospora theridion $(\mathrm{Pt})$ in gills from Atlantic salmon collected in August 2009 in farm SFB

In 2009 there was an outbreak of Flavobacterium psychrophilum in a rainbow trout farm in brackish water in western Norway (HK09-om). Screening of gills and kidney tissue showed that all fish were carriers of $F$. psychrophilum and moderately positive for SAV. The fish were negative for Paranucleospora theridion and VHS virus. The only bacterium that could be cultured from the fish was $F$. psychrophilum.

Salmon in 4 farms (TB08, TH08, TG09, STD09) collected in May all suffered from winter ulcers, and fish in farm STD09 were also given PD as a diagnosis. Moritella viscosa were isolated from the fish in all 4 farms. A few salmon in STD09 were also positive for Paranucleospora theridion (4/13), Parvicapsula pseudobranchicola (4/13) and SAV (3/13). The salmon in the 3 farms in Troms were negative for other known pathogens.

\section{Paranucleospora theridion levels in fish with different diagnoses}

In the area where $P$. theridion infections are common (region from Sør-Trøndelag to Rogaland), average $P$. theridion levels were significantly higher in fish from marine farms with the diagnosis PGI than in fish with other diagnoses $\left(\mathrm{N}_{\mathrm{PGI}}=19, \mathrm{~N}_{\text {other }}=24\right.$ farms $\left.), \mathrm{p}<<0.001\right)$. This result was robust, i.e. not affected by removal of rainbow trout farms and farms from the 2 northernmost counties (Sør-Trøndelag, Møre og Romsdal) from the analysis $\left(\mathrm{N}_{\mathrm{PGI}}=18, \mathrm{~N}_{\text {other }}=15, \mathrm{p}<0.001\right)$. Similar testing did not reveal any significant difference in $P$. theridion levels associated with the diagnoses PD, CMS and HSMI.

\section{DISCUSSION}

Most diseases that occur in the production of salmonids are a result of a combination of factors. These could be environmental changes (changes in factors like temperature, oxygen, algal blooms and fish shoals), human activities (e.g. transport of fish, sorting of fish, delousing) and pathogens (e.g. Lepeophtheirus salmonis, Nucleospora salmonis) weakening the immune defence of the host, increasing susceptibility or permitting proliferation of pathogens already present in the fish. This study is the first attempt to gain a more complete picture of the types and numbers of pathogens that can be involved in the development of diseases in Norwegian production of salmonids with a main focus on PGI, PD, HSMI and CMS. These diseases were selected due to the large discrepancies between the observed pathology and mortality in marine farms compared to what is observed in challenge experiments. PGI is an obvious choice since it is 
already recognised that several pathogens are associated with gill diseases (A. Nylund et al. 1998, 2007, 2008, 2009a,b, Kvellestad et al. 2003, 2005, Draghi et al. 2004, Fridell et al. 2004, Todal et al. 2004, Callahan et al. 2005, Young et al. 2007, 2008, Karlsen et al. 2008, S. Nylund et al. 2008, 2009, 2010, Steinum et al. 2008, 2010), and it has also proven difficult to perform challenge experiments with most of these agents. The other 3 diseases, PD, HSMI and CMS, are all associated with the presence of viruses (Watanabe et al. 1995, 2003, 2006, Vågenes et al. 1999, Nylund 2001, Kongtorp et al. 2004a, McLoughlin \& Graham 2007, Bruno \& Noguera 2009, Fritsvold et al. 2009, Palacios et al. 2010, O. Haugland et al. unpubl.), but it is difficult, in challenge experiments, to reproduce both the mortality and all the pathological changes observed during outbreaks in farms. In the present study we present the pathogens that are associated with these diseases in Norwegian culture of salmonids with a special emphasis on the possible importance of Paranucleospora theridion.

\section{Proliferative gill inflammation}

PGI is mainly a problem for the production of Atlantic salmon in sea cages in western Norway. This suggests a limited distribution of the causative pathogen(s), elevated infection pressure in this region or that high seawater temperatures are important for the development of the disease. Many of the agents that are associated with PGI are commonly found in all areas with salmon farming in Norway; among these are Parvicapsula pseudobranchicola, Ichthyobodo sp., Trichodina spp., SGP virus, and Chlamydia-like species (A. Nylund et al. 1998, 2007, 2008, Todal et al. 2004, Karlsen et al. 2008). Neoparamoeba perurans seem to be mainly distributed in western Norway (A. Nylund et al. 2007, 2008, Steinum et al. 2008), while the available information about the geographical distribution of ASPV limits it to the southwest of Norway (Kvellestad et al. 2003, 2005, Fridell et al. 2004, S. Nylund et al. 2008). Paranucleospora theridion is present in most parts of Norway with sea production of salmonids (A. Nylund et al. 2009a,b, S. Nylund et al. 2009, 2010, present study). However, there is a large difference in prevalence and density of this parasite in salmon kept in western and northern Norway. The salmon suffering from PGI in western Norway all had moderate to extreme amounts of $P$. theridion present in the gill tissues, while only a few lightly infected fish were found among salmon with PGI in northern Norway. The highly significantly elevated $P$. theridion densities associated with PGI and high mortalities in populations of farmed Atlantic salmon during autumn and early winter in western Norway suggest that this pathogen may be a primary agent for the cases of PGI with high mortality. This is also supported by the observed gill pathology, where hyperplasia and hypertrophia are associated with the presence of various developmental stages of $P$. theridion or the degeneration of the same stages of the parasite. Various species of Chlamydialike bacteria ('Candidatus Piscichlamydia salmonis', 'Candidatus Clavochlamydia salmonicola' and a new Chlamydia-like species) may also be present on the gills, but the only host response against these seems to be hypertrophia of the infected epithelial cells. Findings of parasites like P. pseudobranchicola, Ichthyobodo spp., Neoparamoeba perurans and Trichodina spp. in this study are limited to a few cases and in relatively low amounts, with little pathology. $N$. perurans was found in only 1 farm (SFA06-07), and the few cases with relatively high amounts of $P$. pseudobranchicola were all located in northern Norway (farms TA05, TE09, TC09, and FA09). Flavobacterium psychrophilum were isolated from gills of salmon smolt at 2 smolt-production sites, HG09-fw, STB07-fw, where the fish were diagnosed with PGI and HSMI, respectively. In one of the smolt-production sites where seawater was added in the production (STB07), the salmon were lightly infected with $P$. theridion. Hence, salmon smolt may carry infections at sea transfer, but the fate of such infections is unknown. The biology of the parasite, requirements for periods with temperatures above $10^{\circ} \mathrm{C}$ and the fact that the main hosts are salmon lice Lepeophtheirus salmonis (A. Nylund et al. 2009a,b, S. Nylund et al. 2009, 2010), suggest that disease caused by $P$. theridion should be limited to sea production of salmonids in areas with temperatures reaching $15^{\circ} \mathrm{C}$ during summer and autumn. These requirements are most commonly met in western Norway.

\section{Pancreas disease}

The producers of Atlantic salmon in Norway experienced 429 outbreaks of PD in the period 2004 to 2009, and the majority of these outbreaks, $43.6 \%$, occurred in June to August (Fig. 12). In this study, we included material from 12 outbreaks of PD, of which 8 occurred in the period June to August. The salmon in 11 of these farms were moderately to strongly infected with Paranucleospora theridion, and their tissues contained low to moderate amounts of SAV. It has been thoroughly demonstrated that SAV play an important role in the development of PD (Nelson et al. 1995, McLoughlin et al. 1996, McLoughlin \& Graham 2007), and high mortalities have been reported (Taksdal et al. 2007, Fringuelli et al. 2008). However, as several challenge experiments have shown (McLoughlin et al. 


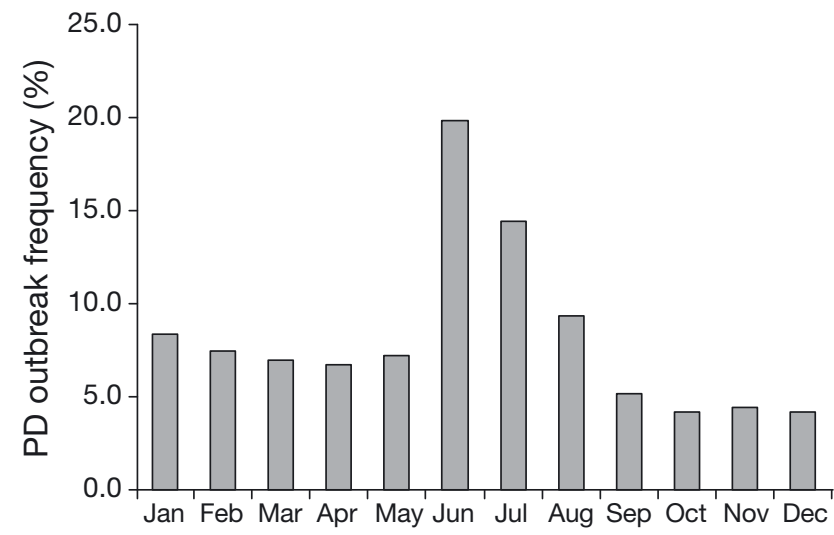

Fig. 12. Pancreas disease (PD) outbreaks in Norway during the period 2004 to 2009 presented as the percentage of the total number $(\mathrm{N}=429)$ of outbreaks in this period. This figure is based on the official records of PD outbreaks in this period. Nearly half $(43.6 \%)$ of the outbreaks occurred in the period June to August

1996, Desvignes et al. 2002, Christie et al. 2007), SAV might not be solely responsible for the PD outbreaks that occur in marine farms for salmonids. While we did not find evidence for elevated $P$. theridion densities in fish from farms diagnosed with PD when compared to those from farms with other diagnoses, $P$. theridion levels were high and may still be important. A challenge experiment using both SAV and $P$. theridion should be performed to monitor the combined effect of these 2 pathogens under controlled conditions.

The salmon in TC09, located in northern Norway, tested negative for the presence of Paranucleospora theridion but were moderately infected with Parvicapsula pseudobranchicola. In northern Norway, other pathogens like $P$. pseudobranchicola could be important as co-infection agents together with SAV in outbreaks of PD. However, more cases of PD in this northern region need to be examined before any conclusion can be drawn.

\section{Heart and skeletal muscle inflammation and cardiomyopathy syndrome}

Several studies have suggested that HSMI and CMS are associated with viruses (Watanabe et al. 1995, 2003, 2006, Vågenes et al. 1999, Nylund 2001, Kongtorp et al. 2004a, Bruno \& Noguera 2009, Fritsvold et al. 2009, Palacios et al. 2010, O. Haugland et al. unpubl.). However, using homogenates containing these viruses in challenge experiments will not reproduce all the signs of these diseases and the mortality observed in field outbreaks (A. Nylund pers. obs.). The present study included samples from salmon suffering from CMS and HSMI in 3 and 7 farms, respectively. In addition, 6 farms with a mixed diagnosis (PGI, PD, HSMI and CMS) were included. HSMI usually starts 5 to 9 mo after release into seawater, in the autumn and early winter, but may occur during the first weeks in sea or even before sea launching (Kongtorp et al. 2004a,b, Watanabe et al. 2006, A. Nylund pers. obs.). The number of cases each year increased from 54 in 2004 to 162 in 2007 according to the official registrations, and 92 cases were registered during the first $6 \mathrm{mo}$ in 2009. This disease is present in all areas with salmon farming in Norway, but with a main focus in central Norway. It is obvious from the distribution of HSMI that co-infections with Paranucleospora theridion are not necessary for the development of the disease. However, this parasite may play a role in the development or severity of HSMI in western and central Norway where moderate to high amounts of $P$. theridion were found in farms (RA06, STA06, STC07, RC07, RE08, RA09) with salmon diagnosed with HSMI. Moderate amounts of SAV were also present in 1 farm (RE08), while no significant amounts of other pathogens were detected in salmon at the other 5 sites. The salmon in other farms (TA05, STB07-fw, TE09, MRF10, MRA06) with HSMI diagnosis were negative for the presence of P. theridion or had only a low amount of the parasite. However, other pathogens were detected in 4 of these farms. Moderate amounts of Parvicapsula pseudobranchicola were present in farms TA05 and TE09, while Moritella viscosa and Flavobacterium psychrophilum seemed to play an important role in the development of disease in farms MRA06 and STB07-fw, respectively. Hence, most cases of HSMI seem to be associated with moderate to high amounts of other pathogens in addition to a presumed responsible viral agent. CMS occurs most often during the last 6 mo before termination of the sea production, i.e. during the second year at sea (Bruno \& Noguera 2009, Fritsvold et al. 2009). It is believed that CMS is caused by viruses (Watanabe et al. 1995, Vågenes et al. 1999, Nylund 2001, Bruno \& Noguera 2009, Fritsvold et al. 2009, O. Haugland et al. unpubl.). CMS is diagnosed on characteristic changes in the atrium and the spongiosum of the ventricle of the heart (Fig. 13). Nodavirus-like particles and other virus-like particles have been detected in the heart of salmon diagnosed with CMS (Watanabe et al. 1995, Grotmol et al. 1997, Nylund 2001). However, nodaviruses are not consistently present in salmon suffering from CMS. In northern Norway, paramyxovirus-like particles can be present in salmon with this disease, and in western Norway, large amounts of a naked $40 \mathrm{~nm}$ large virus-like particle was present in affected heart tissues (Fig. 13C), but it is not known whether the paramyxovirus-like particles are ASP virus. In the present study, we were unable to detect nodavirus or ASP virus in any of the salmon suffering from CMS, which suggests that the particles are probably accidental findings in some cases of CMS or that they do not rep- 



Fig. 13. Salmo salar. Atrium from Atlantic salmon suffering from cardiomyopathy syndrome. (A) Degeneration of the cardiac myofibres and invasion of leukocytes. Scale bar $=50 \mu \mathrm{m}$. (B) Cardiac myofibres substituted by connective tissue. Invasion of melanomacrophages. Scale bar $=20 \mu \mathrm{m}$. (C) Endocardial cell with a vacuole containing paramyxovirus-like particles (arrow). Scale bar $=500 \mathrm{~nm}$. (D) Vacuole (arrow) in a degenerated myofibre containing amorphous material and $40 \mathrm{~nm}$ virus-like particles.

resent viruses. A recent study suggests that a dsRNA virus in the Totiviridae family is responsible for causing CMS (O. Haugland et al. unpubl.). This is supported by our findings of $40 \mathrm{~nm}$ virus-like particles. $P$. theridion may play a part in the development of CMS in salmon kept in western Norway, but as with HSMI, this is a disease that can be found in salmon farms along the Norwegian coast and also in areas where $P$. theridion is of no importance.

\section{Other diseases}

Paranucleospora theridion does not seem to be of importance for the other diseases included in this study. Half of the farms in which other diseases were diagnosed (TB08, TH08, FA09, TD09, TF09 and TG09) are located in northern Norway and, hence, there is no reason to suspect that $P$. theridion could be of importance due to the low summer/autumn temperatures in this area. How- 
ever, the other 6 farms are located in areas where $P$. theridion can occur at high densities in fish tissues. One of these farms (MRB08-om) diagnosed with VHS (cf. Duesund et al. 2010) contained reared rainbow trout showing moderate $P$. theridion densities. It has already been shown that the VHS genogroup-III virus isolated from rainbow trout may cause mortality, but other pathogens present may also have contributed to the mortality observed in the farm (see Duesund et al. 2010).

\section{CONCLUSION}

PGI is associated with a range of different pathogens, viruses, bacteria and parasites, but in western Norway, Paranucleospora theridion seems to be the most important agent in association with PGI and high mortalities. No evidence was found for elevated $P$. theridion densities in fish from farms with diagnoses of PD, HSMI and CMS in western Norway, and these diseases occurred in the absence of the parasite. However, our findings do not exclude a role for this parasite in affecting host susceptibility or disease severity in connection with PD, HSMI and CMS. Further insight into the causes of HSMI and CMS requires knowledge about the biology of viruses associated with these 2 diseases and the development of sensitive and specific diagnostic tools for detection of the viruses in carriers and environmental samples.

Acknowledgements. This work was supported by the University of Bergen and Intervet Norbio.

\section{LITERATURE CITED}

Andersen L, Bratland A, Hodneland K, Nylund A (2007) Tissue tropism of salmonid alphavirus (subtypes SAV1 and SAV3) in experimentally challenged Atlantic salmon (Salmo salar L.). Arch Virol 152:1871-1883

Bruno DW, Noguera PA (2009) Comparative experimental transmission of cardiomyopathy syndrome (CMS) in Atlantic salmon Salmo salar. Dis Aquat Org 87:235-242

Callahan HA, Litaker RW, Noga EJ (2005) Genetic relationships among members of the Ichthyobodo necator complex: implications for the management of aquaculture stocks. J Fish Dis 28:111-128

Christie KE, Graham DA, McLoughlin MF, Villoing S, Todd D, Knappskog D (2007) Experimental infection of Atlantic salmon Salmo salar pre-smolts by i.p. injection with new Irish and Norwegian salmonid alphavirus (SAV) isolates: a comparative study. Dis Aquat Org 75:13-22

$>$ Desvignes L, Quentel C, Lamour F, Le Ven A (2002) Pathogenesis and immune response in Atlantic salmon (Salmo salar L.) parr experimentally infected with salmon pancreas disease virus (SPDV). Fish Shellfish Immunol 12: 77-95

Devold M, Krossøy B, Aspehaug V, Nylund A (2000) Use of RT-PCR for diagnosis of infectious salmon anaemia virus (ISAV) in carrier sea trout Salmo trutta after experimental infection. Dis Aquat Org 40:9-18
Draghi A, Vsevolod LP, Kahl MM, Stanton JB and others (2004) Characterization of 'Candidatus Piscichlamydia salmonis' (Order Chlamydiales), a Chlamydia-like bacterium associated with epitheliocystis in farmed Atlantic salmon (Salmo salar). J Clin Microbiol 42:5286-5297

Duesund H, Nylund S, Watanabe K, Ottem KF, Nylund A (2010) Characterization of a VHS virus genotype III isolated from rainbow trout (Oncorhynchus mykiss) at a marine site of the west coast of Norway. Virol J 7:19

Ferguson HW, Poppe T, Speare DJ (1990) Cardiomyopathy in farmed Norwegian salmon. Dis Aquat Org 8:225-231

Freeman MA, Sommerville C (2009) Desmozoon lepeophtherii n. gen., n. sp., (Microsporidia: Enterocytozoonidae) infecting the salmon louse Lepeophtheirus salmonis (Copepoda: Claigidae). Parasites Vectors 2:58

> Freeman MA, Bell AS, Sommerville C (2003) A hyperparasitic microsporidian infecting the salmon louse, Lepeophtheirus salmonis: an rDNA-based molecular phylogenetic study. J Fish Dis 26:667-676

> Fridell F, Devold M, Nylund A (2004) Phylogenetic position of a paramyxovirus from Atlantic salmon Salmo salar. Dis Aquat Org 59:11-15

> Fringuelli E, Rowley HM, Wilson JC, Hunter R, Rodger $\mathrm{H}$, Graham DA (2008) Phylogenetic analyses and molecular epidemiology of European salmonid alphaviruses (SAV) based on partial E2 and nsP3 gene nucleotide sequences. J Fish Dis 31:811-823

Fritsvold C, Kongtorp RT, Taksdal T, Ørpetveit I, Heum M, Poppe TT (2009) Experimental transmission of cardiomyopathy syndrome (CMS) in Atlantic salmon Salmo salar. Dis Aquat Org 87:225-234

Giovannoni S (1991) The polymerase chain reaction. In: Stackebrandt E, Goodfellow M (eds) Nucleic acid techniques in bacterial systematics. John Wiley and Sons, New York, NY, p 177-201

> Grotmol S, Totland GK, Kryvi H (1997) Detection of a nodavirus-like agent in heart tissue from reared Atlantic salmon Salmo salar suffering from cardiac myopathy syndrome (CMS). Dis Aquat Org 29:79-84

> Hedrick RP, Groff JM, McDowell TS, Willis M, Cox WT (1990) Hematopoetic intranuclear microsporidian infections with features of leukemia in chinook salmon Oncorhynchus tshawytscha. Dis Aquat Org 8:189-197

Hedrick RP, Groff JM, Baxa DV (1991) Experimental infections with Enterocytozoon salmonis Chilmonczyk, Cox, Hedrick (Microsporea): an intracellular microsporidium from chinook salmon Oncorhynchus tshawytscha. Dis Aquat Org 10:103-108

Hodneland K (2006) Salmonid alphavirus (SAV): genetic characterisation of a new subtype, SAV3, and implementation of a novel diagnostic method. $\mathrm{PhD}$ thesis, University of Bergen

> Hodneland K, Endresen C (2006) Sensitive and specific detection of salmonid alphavirus using real-time PCR (TaqMan). J Virol Methods 131:184-192

- Hodneland K, Bratland A, Christie KE, Endresen C, Nylund A (2005) New subtype of salmonid alphavirus (SAV), Togaviridae, from Atlantic salmon Salmo salar and rainbow trout Oncorhynchus mykiss in Norway. Dis Aquat Org 66:113-120

Karlsen M, Nylund A, Watanabe K, Helvik JV, Nylund S, Plarre H (2008) Characterization of 'Candidatus Clavochlamydia salmonicola': an intracellular bacterium infecting salmonid fish. Environ Microbiol 10:208-218

Kongtorp RT, Kjerstad A, Taksdal T, Guttvik A, Falk K (2004a) Heart and skeletal muscle inflammation in Atlantic salmon, Salmo salar L.: a new infectious disease. J Fish Dis $27: 351-358$ 
Kongtorp RT, Taksdal T, Lyngøy A (2004b) Pathology of heart and skeletal muscle inflammation (HSMI) in farmed Atlantic salmon Salmo salar. Dis Aquat Org 59:217-224

Korsnes K, Devold M, Nerland AH, Nylund A (2005) Viral encephalopathy and retinopathy (VER) in Atlantic salmon Salmo salar after intraperitoneal challenge with a nodavirus from Atlantic halibut Hippoglossus hippoglossus. Dis Aquat Org 68:7-15

Kvellestad A, Dannevig BH, Falk K (2003) Isolation and partial characterization of a novel paramyxovirus from the gills of diseased seawater-reared Atlantic salmon (Salmo salar L.). J Gen Virol 84:2179-2189

Kvellestad A, Falk K, Nygaard SMR, Flesjå K, Holm JA (2005) Atlantic salmon paramyxovirus (ASPV) infection contributes to proliferative gill inflammation (PGI) in seawaterreared Salmo salar. Dis Aquat Org 67:47-54

Laudan R, Stolen JS, Cali A (1986) Immunoglobulin levels of the winter flounder (Pseudopleuronectes americanus) and the summer flounder (Paralichthys dentatus) injected with the microsporidan parasite Glugea stephani. Dev Comp Immunol 10:331-340

McLoughlin MF, Graham DA (2007) Alphavirus infections in salmonids - a review. J Fish Dis 30:511-531

McLoughlin MF, Nelson RT, Rowley HM, Cox DI, Grant AN (1996) Experimental pancreas disease in Atlantic salmon Salmo salar post-smolts induced by salmon pancreas disease virus (SPDV). Dis Aquat Org 26:117-124

Muller PY, Janovjak H, Miserez AR, Dobbie Z (2002) Processing of gene expression data generated by quantitative real-time RT-PCR. Biotechniques 32:1372-1379

Nelson RT, McLoughlin MF, Rowley HM, Platten MA, McCormick JI (1995) Isolation of a toga-like virus from farmed Atlantic salmon Salmon salar with pancreas disease. Dis Aquat Org 22:25-32

Nylund A (2001) Cardiac myopathy syndrome (CMS). Fiskehelse 3:29-37 (in Norwegian)

> Nylund A, Hovland T, Watanabe K, Endresen C (1995) Presence of infectious salmon anemia virus (ISAV) in tissues of Atlantic salmon, Salmo salar L, collected during three separate outbreaks of the disease. J Fish Dis 18:135-145

> Nylund A, Kvenseth AM, Isdal E (1998) A morphological study of the epitheliocystis agent in farmed Atlantic salmon. J Aquat Anim Health 10:43-55

Nylund A, Watanabe K, Karlsen M, Nylund S, Karlsbakk E, Sæther PA (2006) New gill disease in Atlantic salmonpoxvirus. Norsk Fiskeoppdrett 31:54-56 (in Norwegian)

Nylund A, Karlsen M, Watanabe K, Karlsbakk E, Nyluns S, Isaksen T, Arnesen CE (2007) A breakthrough in the battle against PGI (proliferative gill inflammation). Norsk Fiskeoppdrett 32:50-53 (in Norwegian)

Nylund A, Watanabe K, Nylund S, Karlsen M, Sæther PA, Arnesen CE, Karlsbakk E (2008) Morphogenesis of salmonid gill poxvirus associated with proliferative gill disease in farmed Atlantic salmon (Salmo salar) in Norway. Arch Virol 153:1299-1309

Nylund A, Watanabe K, Nylund S, Arnesen CE, Karlsbakk E (2009a) A new pathogen - old disease. Norsk Fiskeoppdrett 34:44-49 (in Norwegian)

Nylund A, Watanabe K, Nylund S, Sævareid I, Arnesen CE, Karlsbakk E (2009b) Salmon louse. A biological vector for a salmonid parasite. Naturen 133:217-222 (in Norwegian)

> Nylund S, Karlsen M, Nylund A (2008) The complete genome sequence of the Atlantic salmon paramyxovirus (ASPV). Virology 373:137-148

Nylund S, Nylund A, Watanabe K, Arnesen CE, Karlsbakk E (2009) Paranucleospora theridion n. gen., n. sp. (Micro- sporidia, Enterocytozoonidae) with a life cycle in the salmon louse (Lepeophtheirus salmonis, Copepoda) and Atlantic salmon (Salmo salar). Proc 14th EAFP Meeting, Prague, September 14-19, 2009

Nylund S, Nylund A, Watanabe K, Arnesen CE, Karlsbakk E (2010) Paranucleospora theridion n. gen., n. sp. (Microsporidia, Enterocytozoonidae) with a life cycle in the salmon louse (Lepeophtheirus salmonis, Copepoda) and Atlantic salmon (Salmo salar). J Eukaryot Microbiol 57:95-114

Olsvik PA, Lie KK, Jordal AEO, Nilsen TO, Hordvik I (2005) Evaluation of potential reference genes in real-time RTPCR studies of Atlantic salmon. BMC Mol Biol 6:21

> Palacios G, Lovoll M, Tengs T, Hornig M and others (2010) Heart and skeletal muscle inflammation of farmed salmon is associated with infection with a novel reovirus. PLoS ONE 5:e11487

Plarre H, Devold M, Snow M, Nylund A (2005) Prevalence of infectious salmon anaemia virus (ISAV) in wild salmonids in western Norway. Dis Aquat Org 66:71-79

Poppe TT, Håstein T (1982) Costiasis på laksesmolt (Salmo salar L.) i sjøoppdrett. Norsk Veterinærtidsskr 94: $259-262$

Steinum T, Kvellestad A, Rønneberg LB, Nilsen H and others (2008) First cases of amoebic gill disease (AGD) in Norwegian seawater farmed Atlantic salmon Salmo salar L., and phylogeny of the causative amoeba 18S cDNA sequences. J Fish Dis 31:205-214

Steinum T, Kvellestad A, Colquhoun DJ, Heum M, Mohammad S, Nygaard Grøntvedt R, Falk K (2010) Microbial and pathological findings in farmed Atlantic salmon Salmo salar with proliferative gill inflammation. Dis Aquat Org 91:201-211

Taksdal T, Olsen AB, Bjerkås I, Hjortaas MJ, Dannevig BH, Graham DA, McLoughlin MF (2007) Pancreas disease in farmed Atlantic salmon, Salmo salar L., and rainbow trout, Oncorhynchus mykiss (Walbaum), in Norway. J Fish Dis 30:545-588

> Todal JA, Karlsbakk E, Isaksen TE, Plarre H and others (2004) Ichthyobodo necator (Kinetoplastida) - a complex of sibling species. Dis Aquat Org 58:9-16

Vågenes Ø, Nylund A, Poppe T (1999) Kardiomyopatiysyndrom. In: Poppe $\mathrm{T}$ (ed) Fiskehelse og fiskesykdommer. Universitetsforlaget, Oslo, p 153-154

Villoing S, Bearzotti M, Chilmonczyk S, Castric J, Bremont M (2000) Rainbow trout sleeping disease virus is an atypical alphavirus. J Virol 74:173-183

Watanabe K, Økland S, Krossøy B, Midtun B, Nylund A (1995) Hjertesprekk (CMS): forårsaket av virus? Norsk Fiskeoppdrett 20:28-30

Watanabe K, Devold M, Myhr E, Lyngøy A, Isdal E, Fridell F, Nylund A (2003) Heart and skeletal muscle inflammation (HSMI): a new viral disease? Fiskehelse 5:23-30 (in Norwegian)

- Watanabe K, Karlsen M, Devold M, Isdal E, Litlabø A, Nylund A (2006) Virus-like particles associated with heart and skeletal muscle inflammation (HSMI). Dis Aquat Org 70: 183-192

Young ND, Crosbie PBB, Adams MB, Nowak BF, Morrison RN (2007) Neoparamoeba perurans n. sp., an agent of amoebic gill disease of Atlantic salmon (Salmo salar). Int J Parasitol 37:1469-1481

> Young ND, Dyková I, Snekvik K, Nowak BF, Morrison RN (2008) Neoparamoeba perurans is a cosmopolitan aetiological agent of amoebic gill disease. Dis Aquat Org 78: $217-223$ 